\title{
RC BEAMS STRENGTHENED BY RC JACKETING UNDER LOAD
}

\author{
Zinoviy Blikharskyy ${ }^{\varpi}$ \\ Faculty of Civil Engineering, Czestochowa University of Technology, Częstochowa, Poland
}

\begin{abstract}
This article is devoted to experimental researches of the reinforced concrete beams strengthened by a RC jacketing under load. The program of experimental researches of reinforced concrete beams was envisaged to test four series with a total number of 16 beams 2,100 mm long, of which 14 reinforced beams were additionally pre-loaded. In all experimental samples the longitudinal working reinforcement were steel bars of $2 \varnothing 14 \mathrm{~mm}$ A500C. The beams were reinforced by jacketing with the use of two unstressed reinforcement rods of $2 \varnothing 10 \mathrm{~A} 500 \mathrm{C} \mathrm{mm}$. To simulate the real life conditions, the loading levels of $30 \%, 50 \%, 70 \%$ and $90 \%$ of the non-strengthened beam bearing capacity were maintained during jacketing. The strengthening effect decreased from 92 to $76 \%$ depending on the actual load level (30-90\% of the load-bearing capacity of non-strengthened beams). The results of the study could be taken into account in designing reinforced concrete beams strengthened by a RC jacketing under previous loading.
\end{abstract}

Key words: RC beams, RC jacket, loading, bearing-capacity, strengthening, bending

\section{INTRODUCTION}

At the present stage of economic development, the need for rapid restructuring of production with the use of new high technologies comes to the fore. Changing the equipment is usually associated with an increase in structural loads, which in turn leads to the need to increase the load-bearing capacity of the structures by means of their reinforcement (Blikharskyy, Brózda \& Selejdak, 2018; Blikhars'kyi, 2019).

Reinforced concrete structures are a large part of the load-bearing structures of buildings in the industry, as they are characterized by significant predicted durability and low costs during the operation of structures. Usually, all load-bearing structures of buildings and structures are influenced by load. The level of load may vary: from the weight of the structures to the value of the full operational load. Therefore, to ensure the strength and reliability of the reinforcement of such structures, in addition to ensure the compatibility of the reinforcement materials and the main cross-section of an element, a comprehensive consideration of the presence of load action during the reinforcement of the element is necessary. Therefore, the study of bending elements, especially reinforced by the load, is relevant.

Reinforcement of reinforced concrete structures was investigated by many scientists (Bobalo, Blikharskyy, Kopiika \& Volynets, 2020), what allowed to develop effective structural solutions for strengthening reinforced concrete structures (Ashour, El-Refaie \& Garrity, 2004; Martinola, Meda, Plizzari \& Rinaldi, 2010; Usama, 2011; Krainskyi, Blikharskyy \& Khmil, 2015; Lobodanov, Vegera \& Blikharskyy, 2020; Selejdak, Blikharskyy, Khmil \& Blikharskyy, 2020). However, the analysis shows that most of the performed studies concern the reinforcement of structures without taking into account the effect of loading and the initial stress-strain state caused by it. The effect of magnitude of 
a current load level of the structure on the efficiency of the reinforcement method has also not been sufficiently studied. The magnitudes of correction coefficients of the operating conditions given in the current regulatory documents (Mosley, Hulse \& Bungey, 2012) do not fully correspond to the results obtained experimentally (Blikharskyy, Vashkevych, Vegera \& Blikharskyy, 2020; Krainskyi, Blikharskyy, Khmil \& Vegera, 2020). The purpose of this work was to experimentally test reinforced concrete beams, reinforced with reinforced concrete clamp under load actions of different levels. The efficiency of this method of beam reinforcement is established, depending on the level of acting load. The results will be a basis for a development or improvement of existing methods of calculations of the load-bearing capacity of reinforced concrete beams.

\section{MATERIALS AND METHODS}

The program of experimental researches of reinforced concrete beams was envisaged to test four series with a total number of 16 beams $2,100 \mathrm{~mm}$ long, of which 14 beams were reinforced by load.

The cross-section of the beams was $100 \times 200 \mathrm{~mm}$ with working reinforcement $2 \varnothing 14 \mathrm{~mm}$ of class A500C.

Prism strength of concrete beams for 28 days was $f_{c d}=29 \mathrm{MPa}$, Young modulus of deformation was $E_{c d}=28,500 \mathrm{MPa}$.

In aim to study the effectiveness of the use of reinforced concrete clamp, it was provided a reinforcement of clamp, namely two rods $\varnothing 8 \mathrm{~mm}, \varnothing 10 \mathrm{~mm}$ and $\varnothing 12 \mathrm{~mm}$ A500C. To simulate the real life conditions, the loading level of $30 \%, 50 \%, 70 \%$ and $90 \%$ of the non-strengthened beam bearing capacity was maintained during jacketing. The thickness of the concrete of the casing is $20 \mathrm{~mm}$ across three faces and $40 \mathrm{~mm}$ along the lower elongated face to provide the required protective layer of concrete for additional reinforcement.

Accordingly, the following marking is accepted for the test specimens - "Bs-3.1-0.3", where B denotes the beam, $\mathrm{s}$ - tested for short-term load after reinforcement, 3.1 - the series and number of the test specimen, 0.3 - the load level for which the reinforcement by the clip is performed. To determine the limit load at the first stage of the study, tests were performed on basic, non-reinforced beams of the first series B-1.1 and B-1.2 for the effect of short-term loading.

This article describes the results of studies of series of three beams reinforced with a concrete clip with the same amount of additional reinforcement (two of $10 \mathrm{~mm}$ of class A500C), made at different loading levels equal to $30 \%, 50 \%, 70 \%$ and $90 \%$ of the non-strengthened beam bearing capacity.

In the study of the experimental load samples, two concentrated forces were applied to the upper face of the beams in thirds of the span (Fig. 1).

After loading the beams up to the design level, the load was fixed with the help of a power spring and work was performed on the arrangement of the concrete clip. The technological sequence is shown in Figures 2-5.

No earlier than 28 days after mounting of the device, the reinforced beams were tested by applying a short-term load to failure.

The deflections of the beams were measured using four clock-type deflectors with an accuracy of $0.01 \mathrm{~mm}$. Two of them were mounted on supports on the upper face of the beam. The other two indicators

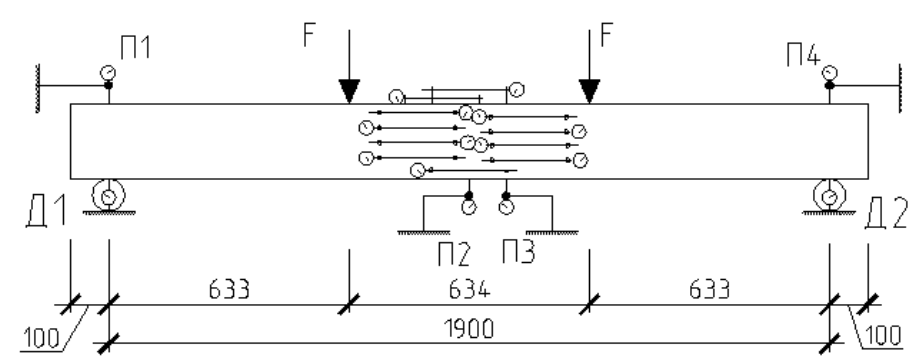

Fig. 1. General view of gauges in experimental sample 
$\mathrm{a}$

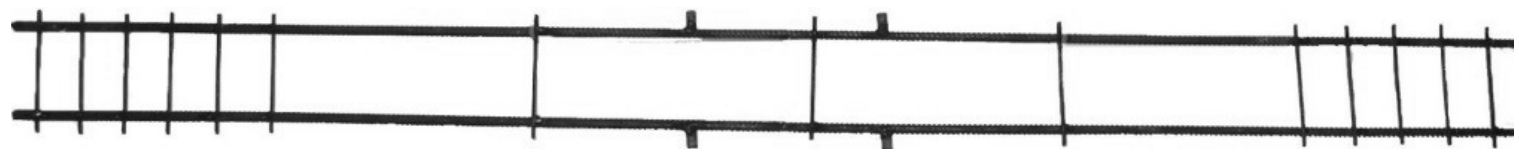

b

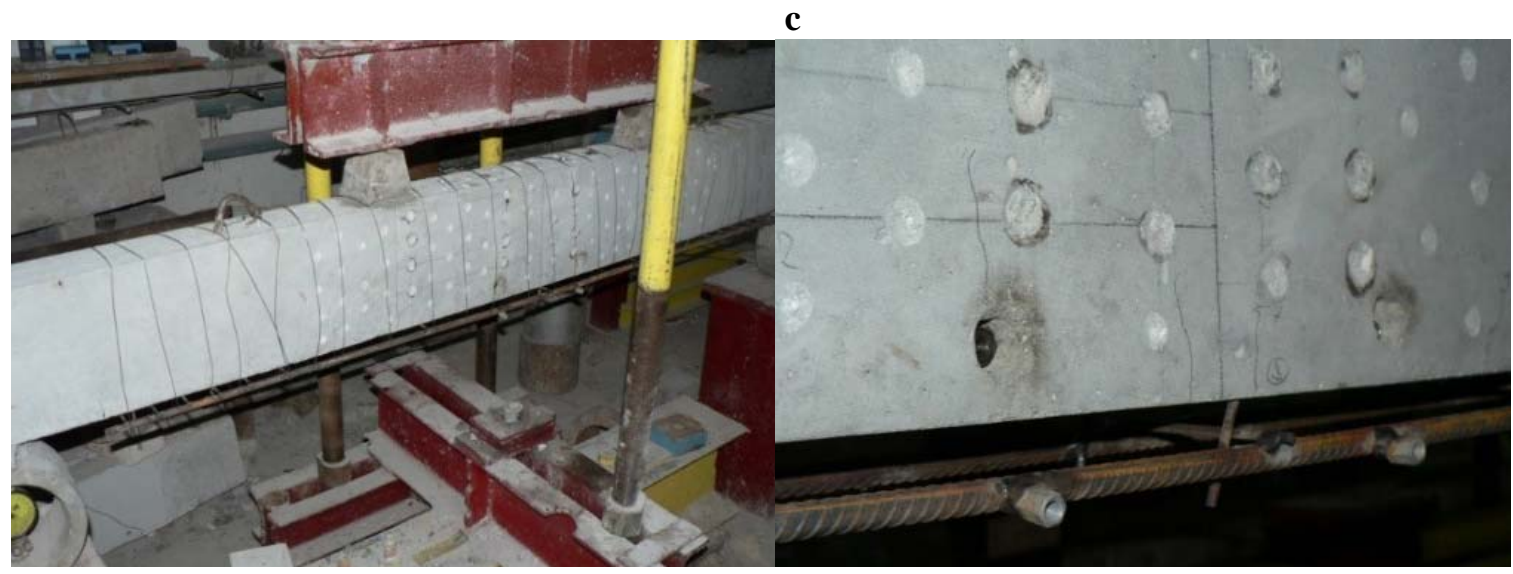

Fig. 2. Scheme (a) and general view (b) of jacket reinforcement and preparation of sample for strengthening (c)

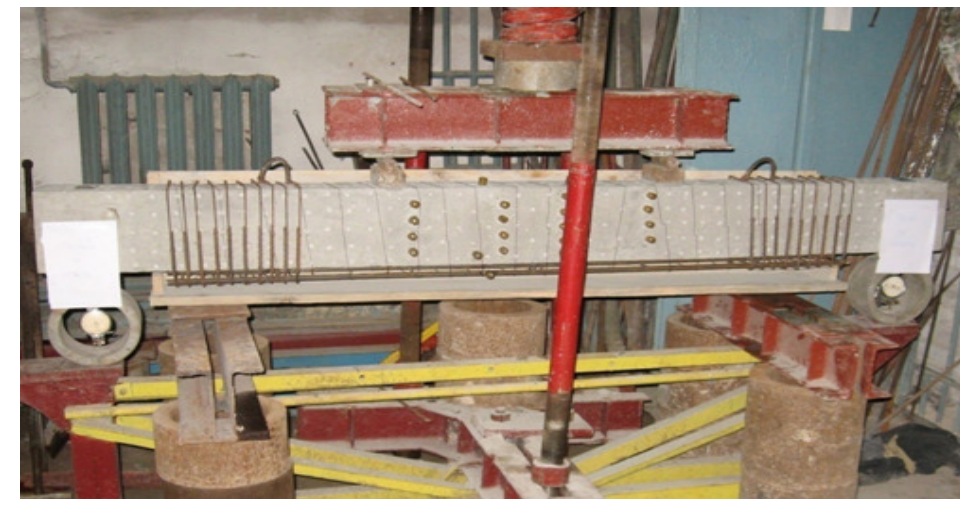

Fig. 3. General view of sample with jacket reinforcement before strengthening

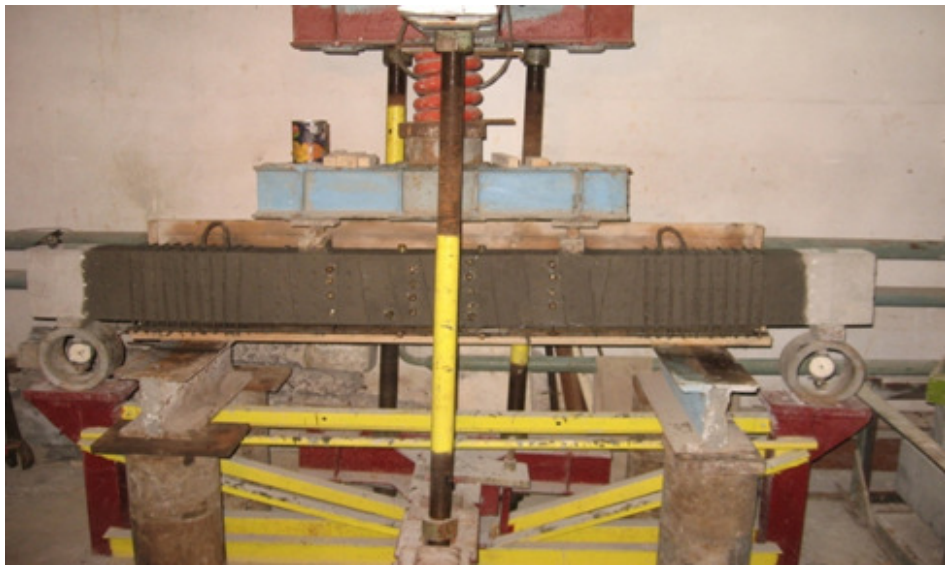

Fig. 4. Application of special glue material Cerinol ZH to the sample 


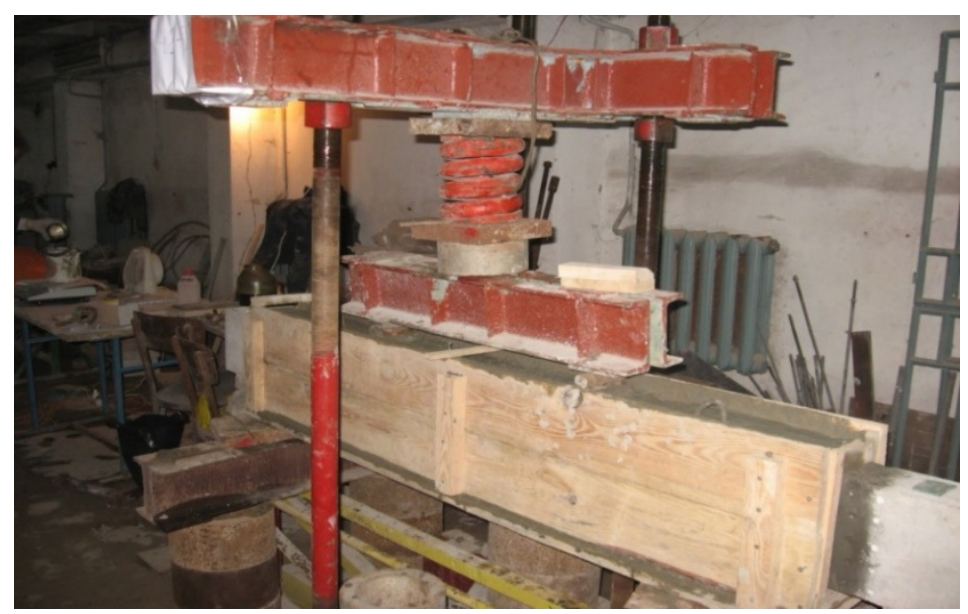

Fig. 5. Application of reinforce concrete jacket to the sample (final process of strengthening)

were mounted on tripods, which remained constant during the deformation of the beam and were brought to the bottom face in the middle of the beam.

The deformations of the beam along the height of the concrete cross section were measured using 19 clocktype micro-indicators with a scale of $0.001 \mathrm{~mm}$. Amongst these nine were placed on "old" concrete and 10 on "new" concrete with base dimensions of approximately $200 \mathrm{~mm}$. The deformations of each rod (main and secondary) were also measured by microindicators with a scale of $0.001 \mathrm{~mm}$. For this purpose, special holders were provided in the process of manufacturing of reinforcement frames. The general layout of the devices during the tests is shown in Figure 6.

\section{RESULTS AND DISCUSSION}

Determination of load and effort, which corresponds to the flow of the reinforcement, was performed according to the obtained graphs of the average relative deformations of the reinforcing rods. After mounting the clamp, a noticeable decrease in the intensity deflection is observed with the same increase in the magnitude of the acting torque. This decrease in the deflection is explained by the fact that the reinforcement increased the geometric dimensions of the cross section, and therefore the stiffness of the section increased. Only in the last stages of loading their increase intensifies, what indicates the beginning of the flow of steel reinforcing

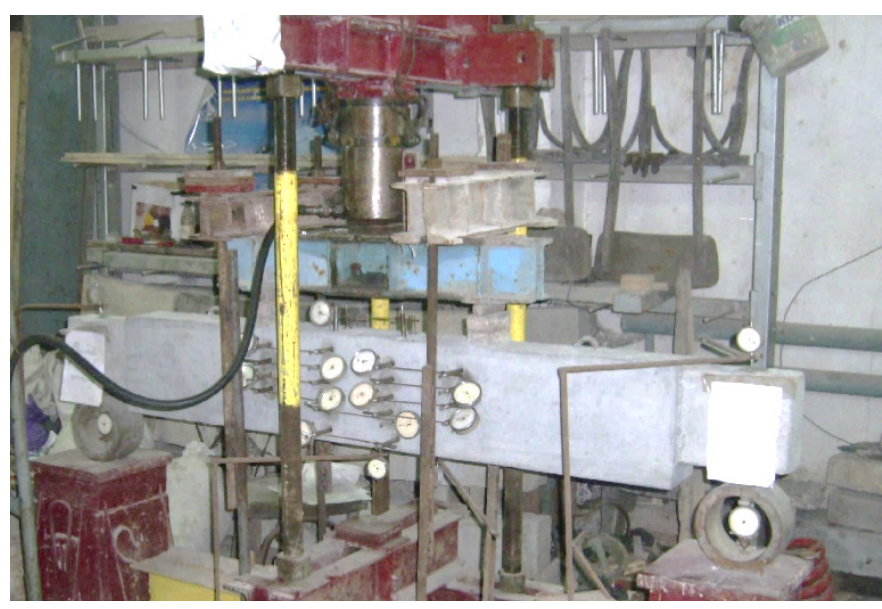

Fig. 6. General view of RC beam strengthened by $\mathrm{RC}$ jacket during test 
bars. A graphic method determined the amount of force corresponding to the flow of the reinforcing rods. The results for all beams are presented in the table.

Since the reinforced concrete beam has two rows of reinforcement (main and in the clip), therefore, the flow occurs in them not at the same time but at different bending moment magnitude. This is explained by a different working height of the reinforcement in the section and the presence of initial stresses in the main reinforcement at the moment of reinforcing.

As a criterion of determination of the bearing capacity of such a complex reinforced structure, it is proposed to assume the magnitude of the bending moment at which the flow occurred in all reinforcing rods, i.e. their deformations reached the limit $\varepsilon_{s} \geq \varepsilon_{s 0}$, and the corresponding stresses - the yield strength $\sigma_{s} \geq f_{y d}$.

Taking into account the accepted criterion of destruction, the effect of reinforcement of the tested beams was determined as the ratio of the greater magnitude of the bending moment corresponding to the yield strength of the reinforcement (main or secondary) in the series to the magnitude of the bending moment of the non-reinforced beams of the first series (the table).
In the case of the reinforced concrete beams, additionally strengthened with jacketing and pre-loaded at the level of $70 \%$ and $90 \%$ of bearing capacity of the non-strengthened beams, yield of the beam reinforcement was reached earlier than in the case of the jacket reinforcement, whereas in the case of the strengthened beams, pre-loaded at the level of $30 \%$ and $50 \%$ of bearing capacity of the non-strengthened beams, yield of the jacket reinforcement was reached earlier than in the case of the beam reinforcement.

This conclusion is valid for this ratio of additional and main reinforcement assumed in the experiment.

The physical destruction of reinforced beams was due to the destruction of the compressed zone of concrete after reaching the flow with all the reinforcement of the beam.

\section{CONCLUSIONS}

The study investigated performances of reinforced concrete beams strengthened with reinforced concrete jacketing and pre-loaded at the level of $30 \%$, $50 \%, 70 \%$ and $90 \%$ of the non-strengthened beam bearing capacity, maintained during jacketing. The

Table. The bearing-capacity of experimental samples

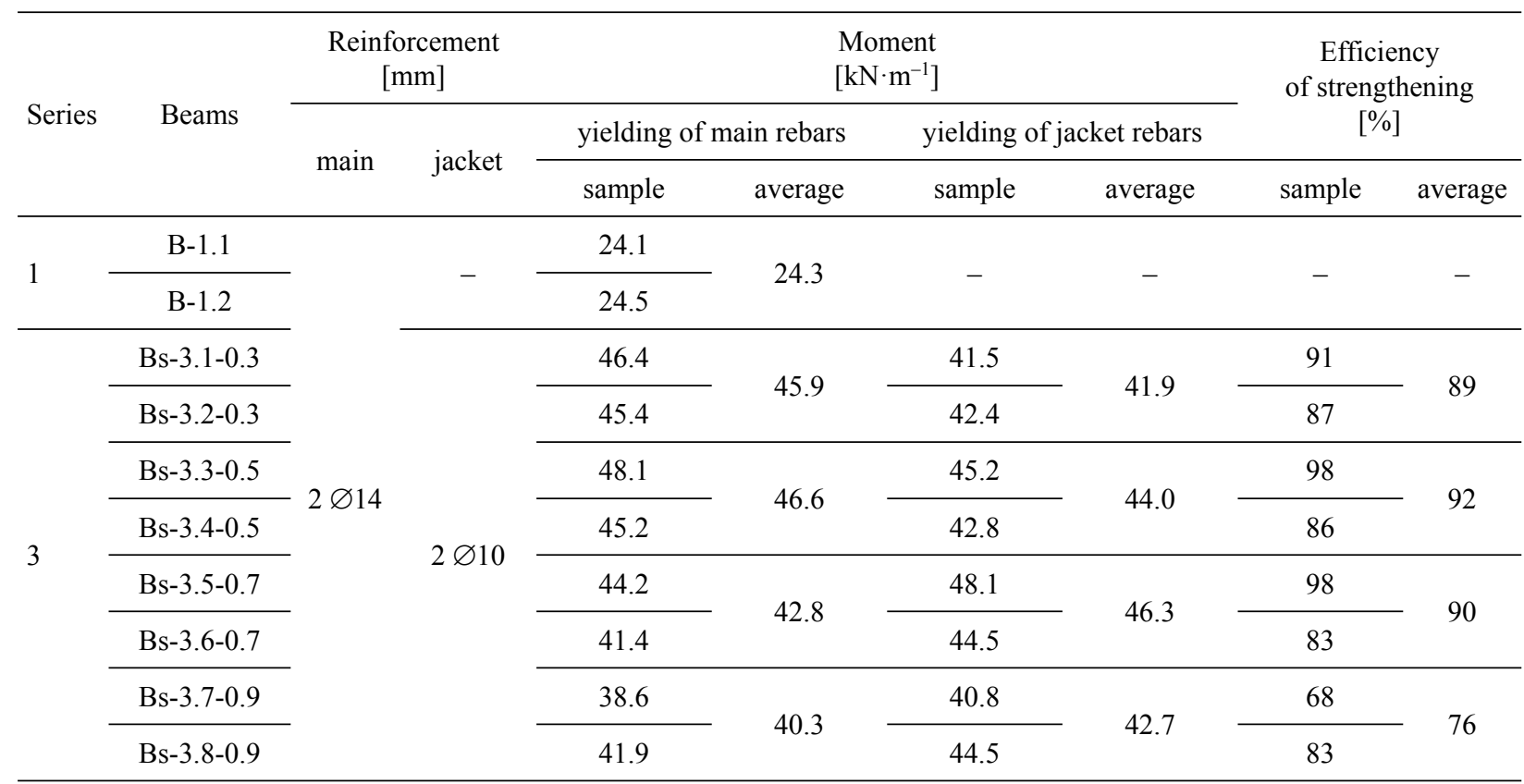


strengthening effect decreased from 92 to $76 \%$ depending on the actual load level $(30-90 \%$ of the load-bearing capacity of non-strengthened beams). The results could be taken into account in designing reinforced concrete beams strengthened by a RC jacketing under previous loading.

\section{REFERENCES}

Ashour, A. F., El-Refaie, S. A. \& Garrity, S. W. (2004). Flexural strengthening of RC continuous beams using CFRP laminates. Cement and Concrete Composites, 26(7), 765-775. https://doi.org/10.1016/ j.cemconcomp.2003.07.002

Blikhars'kyi, Y. Z. (2019). Mechanical properties anisotropy of heat-treated rebar A500S. Materials Science, 55 (2), 175-180. https://doi.org/10.1007/s11003-019-00285-0

Blikharskyy, Z., Brózda, K. \& Selejdak, J. (2018). Effectivenes of Strengthening Loaded RC Beams with FRCM System. Archives of Civil Engineering, 64 (3), 3-13. https://doi.org/10.2478/ace-2018-0025

Blikharskyy, Z., Vashkevych, R., Vegera, P. \& Blikharskyy, Y. (2020). Crack Resistance of RC Beams on the Shear. Lecture Notes in Civil Engineering, 47, 17-24. https:// doi.org/10.1007/978-3-030-27011-7_3

Bobalo, T., Blikharskyy, Y., Kopiika, N. \& Volynets, M. (2020). Serviceability of RC Beams Reinforced with High Strength Rebar's and Steel Plate. Lecture Notes in Civil Engineering, 47, 25-33. https://doi.org/10.1007/978-3030-27011-7_4
Krainskyi, P., Blikharskyy, Z. \& Khmil, R. (2015). Serviceability of reinforced concrete columns strengthened by reinforced concrete jacketing. Zeszyty Naukowe Politechniki Częstochowskiej. Budownictwo, 171 (21), 139-143.

Krainskyi, P., Blikharskyy, Y., Khmil, R. \& Vegera, P. (2020). Crack Resistance of RC Columns Strengthened by Jacketing. Lecture Notes in Civil Engineering, 47, 195-201. https://doi.org/10.1007/978-3-030-27011-7_25

Lobodanov, M., Vegera, P. \& Blikharskyy, Z. (2020). Planning Experiment for Researching Reinforced Concrete Beams with Damages. Lecture Notes in Civil Engineering, 47, 243-250. https://doi.org/10.1007/978-3-03027011-7_31

Martinola, G., Meda, A., Plizzari, G.A. \& Rinaldi, Z. (2010). Strengthening and repair of RC beams with fiber reinforced concrete. Cement and Concrete Composites, 32 (9), 731-739. https://doi.org/10.1016/ j.cemconcomp.2010.07.001

Mosley, W. H., Hulse, R. \& Bungey, J. H. (2012). Reinforced concrete design: to Eurocode 2. 7th ed. London: Macmillan International Higher Education: Red Globe Press.

Selejdak, J., Blikharskyy, Y., Khmil, R. \& Blikharskyy, Z. (2020). Calculation of Reinforced Concrete Columns Strengthened by CFRP. Lecture Notes in Civil Engineering, 47, 400-410. https://doi.org/10.1007/978-3-03027011-7 51

Usama, E. (2011). Hybrid Externally Bonded/Mechanically Fastened Fiber-Reinforced Polymer for RC Beam Strengthening. ACI Structural Journal, 108 (6), 669-678. https://doi.org/10.14359/51683365

\section{BELKı ŻELBETOWE WZMOCNIONE PŁASZCZEM ŻELBETOWYM POD OBCIAZŻENIEM}

\section{STRESZCZENIE}

W artykule przedstawiono badania eksperymentalne belek żelbetowych wzmocnionych płaszczem żelbetowym pod obciążeniem. Program badań eksperymentalnych belek żelbetowych obejmował analizę 4 serii o łącznej liczbie 16 belek, których długość wynosiła $2100 \mathrm{~mm}$, z czego 14 wzmocnionych belek zostało wcześniej dodatkowo obciążonych. Wszystkie badane próbki zostały wzmocnione zbrojeniem podłużnym, które stanowiły pręty stalowe $2 \varnothing 14 \mathrm{~mm}$ A500C. Belki wzmocniono płaszczem żelbetowym, którego zbrojenie stanowiły pręty zbrojeniowe $2 \varnothing 10 \mathrm{~mm}$ A500C. Aby zasymulować rzeczywiste warunki eksploatacji, podczas wzmacniania belek zastosowano różne poziomy obciążenia, a mianowicie $30 \%, 50 \%, 70 \%$ i $90 \%$, dla granicznej nośności niewzmocnionych belek. Na podstawie badań stwierdzono, że efekt wzmocnienia belek zmniejszył się z 92 do 76\% w zależności od poziomu aktualnego obciążenia (30-90\% nośności belek niewzmocnionych). Uzyskane wyniki badań eksperymentalnych mogą zostać uwzględnione w projektowaniu belek żelbetowych wzmocnionych płaszczem żelbetowym po ich wcześniejszym obciążeniu.

Słowa kluczowe: belki żelbetowe, płaszcz żelbetowy, obciążenie, nośność, wzmocnienie, zginanie 